TRANSPACIFIC FEMININITIES 



\section{TRANSPACIFIC FEMININITIES}

THE MAKING OF THE MODERN FILIPINA

Denise Cruz

Duke University Press Durham \& London 2012 
(C) 2012 Duke University Press

All rights reserved

Printed in the United States of America on

acid-free paper $\infty$

Designed by Amy Ruth Buchanan

Typeset in Quadraat by Keystone Typesetting, Inc.

Library of Congress Cataloging-in-Publication

Data appear on the last printed page of

this book.

An earlier version of chapter 5 appeared in

American Quarterly, Volume 63, Issue I, March

201I, pages I-32. Copyright $\left({ }^{\circ} 2011\right.$ The

American Studies Association. 
For JEB and NWB 
